\title{
Growth, Debt, and Inequality
}

\author{
Francesco Marchionne and Sunny Parekh ${ }^{1}$
}

\begin{abstract}
After the 2009 global recession, many papers identified a non-linear inverted Ushaped relationship between economic growth and sovereign debt. However, their results are mixed regarding the exact turning point. According to the traditional view, we assume debt-to-growth causality and show that the mixed results depend on the heterogeneity of the non-linear debt-growth relationship. In our sample of 27 countries over the period 1994-2010, countries with a higher Gini index, our measure of income inequality, show lower threshold points upon which further increases in debt reduce growth, but a higher sensitivity of growth to debt changes. Hence, the more even the income distribution, the more a country should be fiscally virtuous to avoid affecting growth. The implication is that policies promoting a more equal income distribution reduce (increase) economic growth in (not) highly indebted countries.
\end{abstract}

\section{INTRODUCTION}

$\mathrm{I}$ $\mathrm{N}$ CONTEMPORARY HISTORY, sovereign debt accumulation in developed countries has been generally slow, with rapid build-up occurring only in times of war (Checherita and Rother 2012). But, many developed economies have recently experienced an explosion of sovereign debt, in particular in Europe. In the United States and the United Kingdom, for example, debt-to-GDP ratios rose respectively from 52.0 per cent and 40.2 per cent in 2001 , to 93.8 per cent and 103.2 per cent in 2012 (World Bank 2013). As the debt-growth relationship is theoretically unclear and remains empirically mixed, this increasing level of sovereign debt has renewed the debate on this topic. In this paper, we hypothesise an inverted U-shaped relationship between sovereign debt and economic growth, dependent upon income inequality. To motivate our heterogeneous non-linear hypothesis, we draw on the link between growth and debt and on the link between inequality and debt.

There is a rich literature analysing the relationship between the accumulation of sovereign debt and its subsequent effect on economic growth. In a model with finite lived agents, Modigliani (1961) shows that sovereign debt 
promotes economic growth. But he also sheds light on potential negative effects to finance a larger debt for future generations. In Barro (1974), perfectly informed and infinitely lived agents reduce their actual consumption when government expenditure rises, because they anticipate future tax increases. Therefore, Ricardian equivalence implies an insignificant impact of sovereign debt on economic growth. If the assumption of perfect information is also relaxed, creditors do not expect to be fully reimbursed of extensive sovereign debts, and the optimal solution becomes a debt overhang, because an economically unsustainable debt would impact negatively on the probability of servicing the debt and, hence, economic growth (Krugman 1988).

Since Krugman (1988), the bulk of the theoretical literature points towards a negative relationship between sovereign debt and economic growth (Saint-Paul 1992, Elmendorf and Mankiw 1999). The general intuition is that because governments should adopt expansionary fiscal policies in times of recession (to promote economic recovery) and contractionary fiscal policies in times of prosperity (to control sovereign debt levels), sovereign debt and economic growth should be negatively correlated with a time lag (Blanchard 2006). However, the extent of this correlation remains questionable (Patillo et al 2004, Aizenman et al 2007, Cochrane 2011). More recently, Aschauer (2000) assumes that debt is used to finance public capital and infers a nonlinear inverted U-shaped impact of sovereign debt on economic growth, from the non-linear impact of public capital on economic growth. The accumulation of sovereign debt in the short term has a positive effect on economic growth, but there comes a threshold point whereby any further indebtedness increases the risk premium and could lead to a negative net impact on economic growth, through a higher cost of borrowing.

The recent global recession has renewed the debate on the debt-growth nexus, moving the focus of interest from an unclear theoretical prediction to an empirical issue. The debate has focused on the potential detrimental effects of debt on growth and its financial sustainability over time. Applying simple correlation statistics to a dataset of 44 developed and developing countries, Reinhart and Rogoff (2010) find a weak underlying positive link between debt and growth at normal to medium levels of debt, and a negative relationship between high levels of debt and economic growth. In particular, economic growth reduces by 1 per cent when debt exceeds 90 per cent of GDP. ${ }^{2}$ To check this threshold, Caner et al (2010) split the same sample into countries with debt-to-GDP ratios higher and lower than 90 per cent, and they employ more sophisticated pooled least squares regressions. The impact of debt on growth is negative beyond 90 per cent debt-to-GDP ratio, but insignificantly positive below the threshold level, thus only partially corroborating Reinhart and Rogoff's (2010) results. Their analysis combines both time series data and cross sectional data, but serial correlation may still cause biased results (Podestà 2002). Using different measures of government debt and economic growth, Kumar and Woo (2010) find that a 10 percentage point increase in ini- 
tial debt-to-GDP ratio decreases annual GDP per capita by 0.2 per cent per year. Therefore, once again the findings corroborate the relationship established by Reinhart and Rogoff (2010), but suggest a different impact. In brief, despite the majority of the empirical literature pointing towards a non-linear inverted U-shape relationship, mixed results cannot solely be justified as a result of the use of different datasets or methodologies.

Critiques of the non-linear debt-growth relationship move in three different directions. The first rejects the inverted U-shaped relationship. Cochrane (2011) assumes uncertainty about future inflation and shows that extensive sovereign debt levels can reduce consumption levels. In this case, sovereign debt could reduce economic growth even in the short term (Diamond and He 2013). Schclarek (2004) estimates a statistically significant negative linear relationship between external government debt and GDP per capita. Herndon et al (2013) replicate Reinhart and Rogoff's (2010) results using the same methodology and dataset, and find a 2.2 per cent slowdown in economic growth for countries with debt-to-GDP ratio higher than 90 per cent, but no evidence of an inverted U-shaped relationship.

The second critique is about the causality of the growth-debt nexus. Although there is substantial empirical evidence suggesting a correlation between sovereign debt and economic growth, this does not imply causation. Reinhart et al (2012) argue that causality runs from debt to growth, but they also suggest that low levels of economic growth could be the reason for high levels of sovereign debt. Panizza and Presbitero (2013) point out that a negative correlation is created automatically as a result of using debt as a ratio to GDP, thus making the causality difficult to establish. Consequently, there are no papers making a definitive case with regards to a causal relationship between public debt and economic growth.

The last direction of criticism extends the non-linearity notion, suggesting that country-specific variables may affect the degree of debt-growth non-linearity and, hence, each country's debt-to-GDP threshold level (Panizza and Presbitero 2013). Eberhardt and Presbitero (2013) address cross-country heterogeneity by studying different crisis periods in different countries. They confirm the non-linear relationship between government debt and economic growth, but find no evidence of similar threshold level across different countries. This suggests that homogenous policy to control debt may not have the desired affects in every country. Khan and Senhadji (2000) and Khan et al (2001) use a large sample of countries and show that heterogeneity is related to financial depth and inflation. Moreover, finance impacts differently on growth for oil exporters and resource-based economies (Nili and Rastad 2007, Beck 2011). More recently, Arcand et al (2012) find that the non-linear impact of banking depth on growth weakens at very high levels of banking depth. Kourtellos et al (2015) suggest that the relationship between economic growth and sovereign debt may also be influenced by a third variable such as trade openness. ${ }^{3}$

A natural extension of the intuition of Kourtellos et al (2015) is to test 
if the non-linear debt-growth nexus is affected by other variables and whether this heterogeneity explains mixed empirical results. Kuznets (1955) and Williamson (1965) hypothesise that when development sets in, the equal income distribution pattern is broken by entrepreneurs at the forefront, but once a country is fully developed, welfare states redistribute income more fairly. Banerjee and Duflo (2003) corroborate empirically this inverse U-shaped relationship between income inequality and economic development.

To investigate specifically the growth-inequality nexus, Shin (2012) develops a stochastic optimal growth model with heterogeneous agents. Figure 1 illustrates the conceptual framework. According to the Kuznets curve, income inequality first increases and then decreases with economic development (quadrant IV in both diagrams). The 45 degree line in quadrant III reports GDP per capita level in the growth framework (quadrant II). Under the assumption of absolute $\beta$ convergence (Diagram A), the growth-inequality relationship is positive for developed countries and negative for developing countries (quadrant I). This pattern is confirmed by Barro's (2000) result using panel data. He finds that a more uneven income distribution in poor countries leads to inertia in economic growth, whereas more even income distribution leads to increasing growth levels in richer countries.

Figure 1. Conceptual framework
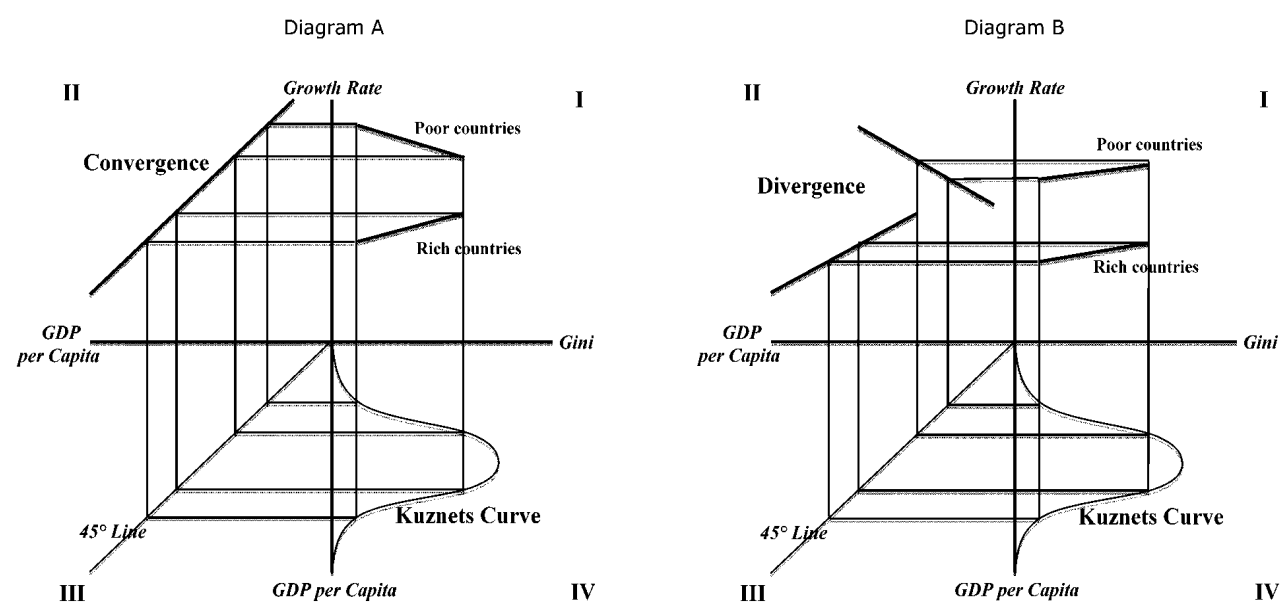

Note: Diagram A reports Figure 1 in Shin (2012). Diagram B assumes conditional convergence according to the main literature with convergence in developed countries and divergence in the developing countries.

However, absolute $\beta$ convergence can be applied only to Organisation for Economic Co-operation and Development (OECD)countries (e.g. Baumol 1986). In a larger sample, there is conditional convergence (e.g. Mankiw et al 
1992) or, probably, divergence (Pritchett 1997). Diagram B shows a positive growth-inequality nexus under economic divergence for developing countries: it suggests a more complex, rather than a monotonic, relationship between the Gini coefficient and the economic growth rate. Recently, Barro $(2008$, p.2) reexamined this relationship, employing a cross-country regression framework and concluded that the overall effect of income inequality on economic growth was weak and, often, statistically insignificantly different from zero. [...] These results could be interpreted from the perspective of some of the underlying theoretical models. In particular, the differing effects for poor and rich could reflect the greater impact of credit market restraints in poor countries. ${ }^{24}$

Beyond the mixed direct impact, income inequality could have an indirect effect on economic growth, through the relationship between finance and development. There are two main explanations for this. The first is that the higher the income inequality, the higher the benefit of debt in stabilising the economy. In the model of Kumhof and Ranciere (2010 p 3), the 'rise of workers' debtto-income ratios generates financial fragility.' Governments issue debt to support lower income individuals and prevent a financial crisis because a stable economy grows more and, hence, absorbs a higher level of debt. The more even the income distribution, the lower the benefit of debt on growth. The second depends on the time horizon of the elite in power. When the income distribution is uneven, the elites in power have stronger control and, hence, a greater incentive to use debt to promote growth, because they will reap the benefits of economic development. In countries with a more even income distribution, elites are weaker as a result of the fiercer competition and, hence, their time horizon is shorter: the impact of debt on growth is lower because debt is used to get an immediate benefit. The final outcome is a growth-debt relationship changing with the income distribution.

In this paper, we test the hypothesis of a non-linear heterogeneous relationship between sovereign debt and economic growth. We suggest that the reason for mixed results (different threshold points in the debt-growth relationship) comes from changes in country specific levels of income inequality. As income inequality data cover too short a period for a Granger analysis, we assume the traditional one-way causality from debt to growth. Our panel regression analysis shows that the growth-debt relationship is more intense, and the threshold level is lower, in countries with more equal income distribution than where income distribution is more unequal. We further check the robustness of our results using different specifications, sub-periods and sub-samples. All of these exercises corroborate the results obtained from our main framework.

The paper proceeds in the following manner. Section 2 describes the empirical framework. Section 3 presents descriptive statistics. Our main findings are presented in Section 4. The next section is devoted to robustness analysis. Finally, the last section includes our concluding remarks along with suggestions for future research. 


\section{EMPIRICAL FRAMEWORK}

We derive our basic specification model, Standard, from the multivariate linear equation used by Checherita and Rother (2012):

$$
y_{i t}=\alpha+\beta D E B T_{i t}+\theta C T R L_{i t}+\varepsilon_{i t}
$$

Where $i$ indicates the country, $t$ denotes the year, and $y_{i t}$ is the GDP per capita growth rate computed over 5 years, from time $t$ to time $t+4$. DEBT is the gross government debt as a percentage share of GDP. CTRL stands for the vector of influential variables identified by the economic literature, which are understood to have an effect on levels of economic growth. The control variables are inflation and exports as proxies for risk and trade openness respectively, population as a measure of country size, and age dependency to take into account the burden of the welfare state. ${ }^{5} \mathrm{We}$ do not include investment because of multicollinearity with other variables and the presence of missing values, that reduces further the size of the sample. Human capital is excluded because standard proxies such as primary, secondary and tertiary schooling enrolment rates are virtually invariant and, hence, collinear with country effects. In choosing between these variables and including fixed effects for countries, in both cases we prefer country effects because they can capture other omitted variables (see Section IV). Finally, we use real GDP per capita as used in Barro's (1996) growth model. $\varepsilon_{\mathrm{i}}$ is an idiosyncratic error term which accounts for disturbances within the panel data.

To account for country specific features, we apply country fixed effects $(\mathrm{FE})$ and random effects $(\mathrm{RE})$ to our regressions. We employ the Hausman test (1978), the Breusch Pagan (1979) Lagrange Multiplier test and the likelihood ratio test to determine the most appropriated estimator. ${ }^{6}$ For all our estimates, we use robust standard errors to control for heteroskedasticity in the residuals. According to a Keynesian view, we assume that an increase in debt to GDP promotes short-run economic growth $(\mathrm{H} 1: \beta>0)$. On the other hand, an insignificant or zero coefficient is a necessary (but not sufficient) condition for Ricardian equivalence.

We adopt a benchmark specification similar to that used in the majority of the empirical debt-growth literature (e.g. Kumar and Woo 2010, Reinhart and Rogoff 2010). To check for the non-linear relationship, we modify this specification in Non Linear as follows:

$$
y_{i t}=\alpha+\beta D E B T_{i t}+\gamma D E B T_{i t}^{2}+\theta C T R L_{i t}+\varepsilon_{i t}
$$

The quadratic term $D E B T^{2}$ allows us to test the non-linearity relationship between government debt and economic growth. Empirically, the relationship of government debt is seen to come to a tipping point where increases in government debt subsequently have a negative effect on growth (Ghosh et al 2011). In theory, we expect a positive $D E B T_{i t}$ coefficient (H2.a: $\beta>0$ ) and a neg- 
ative $D E B T_{\text {it }}{ }^{2}$ coefficient (H2.b: $\gamma<0$ ), in order to observe an inverted U-shape relationship similar to Checherita and Rother (2012). We include the same vector of controls and the error term as in the benchmark, and also apply both fixed effects (FE) and random effects (RE) models to our specification using robust standard errors, as in the standard specification, to maintain comparability of results.

Many papers focus intently on the non-linearity between government debt and economic growth, by attempting to identify the threshold debt level that leads to a consequent decline in economic growth. We hypothesise that income distribution within a country creates a heterogeneous relationship between sovereign debt and economic growth across countries. We use the Gini index (Gini 1921) as a measure of income inequality within a population, because it is able to capture income inequality better than alternative measures. Gobbin et al (2007) show that other proxies such as the decile ratio are easier to determine, but are much more imprecise and the bias that they introduce in the estimates is greater than the advantage of using a larger dataset. They conclude that the Gini index is one of the best proxies for income inequality. Moreover, as this index includes residents and non-residents, it is consistent with the use of GDP. To test the heterogeneous effect of government debt on economic growth, we interact the Gini index with the debt-to-GDP ratio and we obtain the following Heterogeneity equation:

$$
y_{i t}=\alpha+\beta D E B T_{i t}+\delta D E B T_{i t} * G I N I_{i t}+\theta C T R L_{i t}+\varepsilon_{i t}
$$

Where $D E B T * G I N I$ is our interaction term. If our hypothesis is true, we should observe a significant positive coefficient on $D E B T$ (H3.a: $\beta>0$ ) and a significant negative coefficient on $D E B T * G I N I(\mathrm{H} 2.3: \delta<0)$, thus providing evidence of a positive linear relationship, which is lower for more unequal countries.

Further, we combine equations (2) and (3) to test whether there is a non-linear heterogeneous relationship. As suggested by the literature, we assume there to be a parabolic (inverted U-shape) relationship. However, we expand on this by suggesting that there are different parabolic relationships in different countries, depending on their individual levels of income inequality. Our last hypothesis assumes that governments of countries with unequal income distributions benefit elites and lobbies, taking from general economic growth. According to Barro (2000), this implies a flatter parabolic relationship between government debt and economic growth for more unequal countries. Thus, our final specification Non Linear Heterogeneity, including squared terms, is as follows:

$$
\begin{aligned}
y_{i t}= & \alpha+\beta D E B T_{i t}+\gamma D E B T_{i t}^{2}+\delta D E B T_{i t} * G I N I_{i t} \\
& +\zeta D E B T_{i t}^{2} * G I N I_{i t}+\theta C T R L_{i t}+\varepsilon_{i t}
\end{aligned}
$$


We introduce $D E B T^{2}$ and $D E B T^{2} *$ GINI to test the hypothesis of a non-linear heterogeneous relationship. We expect an inverted U-shaped curve on the terms $D E B T$ and $D E B T^{2}$ (HYP4.a: $\beta>0$ and HYP4.: $\gamma<0$ ) and opposite signs for the linear and quadratic interactive terms, $D E B T * G I N I$ and $D E B T^{2}{ }^{*} G I N I$ (HYP4.c: $\delta<0$ and HYP.d: $\zeta>0$ ). Given this, we expect there to be different parabolic relationships present within our data, indicating non-linear heterogeneity.

\section{DATA AND DESCRIPTIVE STATISTICS}

Our data set includes 27 countries; see Table 1 . We collect data from different sources. The majority of our data are from the World Development Indicators (WDI) database by the World Bank (2013). It is comprised of many developmental indicators that are updated quarterly. For consistency with data from other sources, we can rely only on annual data. Because of missing values, we also integrate some of our data with information from other datasets.

\begin{tabular}{lll}
\hline \multicolumn{3}{c}{ Table 1: List of countries used in the dataset } \\
\hline \multicolumn{2}{c}{ Developed countries } \\
Australia & Greece & $\begin{array}{c}\text { Developing } \\
\text { countries no (OECD) }\end{array}$ \\
Austria & Hungary & Brazil \\
Belgium & Italy & China \\
Canada & Luxembourg & Colombia \\
Chile & Mexico & Costa Rica \\
Denmark & Netherlands & Dominican Republic \\
Finland & Norway & Honduras \\
France & Sweden & Panama \\
Germany & United Kingdom & Paraguay \\
\hline
\end{tabular}

Table 2 reports the full list of variables. Our control variables include Inflation, Exports, Population, GDP per capita and the Age Dependency ratio. ${ }^{7}$ Finally, our data for the Gini Index come from World Institute for Development Economics Research (2013) under the United Nations University. 8 This variable is our proxy for income inequality.

We collect data across a time period of 17 years from 1994-2010, the logic being to exclude global macroeconomic shocks such as the reaction to the collapse of the Soviet Union in 1991 and the adjustment following the withdrawal of the United Kingdom and Italy from the European Exchange Rate Mechanism (ERM) in 1992. Both of these events created not only huge direct economic shocks within the countries involved, but also further large indirect shocks in the global economy. Therefore, by excluding these years, we prevent any starting biases occurring within our estimates. 
Table 2: List of variable descriptions

\begin{tabular}{|c|c|c|c|c|c|c|c|c|c|c|}
\hline Variable & \multicolumn{7}{|c|}{ Description } & \multicolumn{3}{|c|}{ Source } \\
\hline GDPPCG & \multicolumn{7}{|c|}{ GDP per capita growth (Annual percentage change) } & \multicolumn{3}{|c|}{ World Bank } \\
\hline$D E B T$ & \multicolumn{7}{|c|}{ Government Debt (percentage share of GDP) } & \multicolumn{3}{|c|}{ World Bank } \\
\hline GINI & \multicolumn{7}{|c|}{ The Gini Index (measure of income inequality) } & \multicolumn{3}{|c|}{$\begin{array}{l}\text { World Institute for } \\
\text { D e v e 1op e } \mathrm{m} t \\
\text { Economic Research }\end{array}$} \\
\hline GDPPC & \multicolumn{7}{|c|}{ GDP per capita GDP divided by midyear population (actual terms) } & \multicolumn{3}{|c|}{ World Bank } \\
\hline INFLATION & \multicolumn{7}{|c|}{ Inflation (annual percentage change) } & \multicolumn{3}{|c|}{ World Bank } \\
\hline EXPORTS & \multicolumn{7}{|c|}{ Exports (percentage share of GDP) } & \multicolumn{3}{|c|}{ World Bank } \\
\hline POPULATION & \multicolumn{7}{|c|}{ Population (actual terms) } & \multicolumn{3}{|c|}{ World Bank } \\
\hline$A G E D E P E N D$ & \multicolumn{7}{|c|}{ Age Dependency Ratio (ratio dependents to working population) } & \multicolumn{3}{|c|}{ World Bank } \\
\hline CREDIT & \multicolumn{7}{|c|}{ Domestic Credit to Private Sector ( percentage of GDP) } & \multicolumn{3}{|c|}{ World Bank } \\
\hline INTERNET & \multicolumn{7}{|c|}{ Internet Users (per 100 people) } & Wo & rld Bank & \\
\hline & & & Table 3. & escripu & Statistics & & & & & \\
\hline Variables & Mean & $S D$ & Min & $p 25$ & Median & (b) & $p 75$ & & $\operatorname{Max}$ & o. Obs \\
\hline & & & All c & ountries & & & & & & \\
\hline$G D P P C G$ & 0.0449 & 0.0562 & -0.128 & 0.016 & 0.042 & & 0.07 & & 0.273 & 459 \\
\hline$D E B T$ & 0.5455 & 0.289 & 0.061 & 0.341 & 0.522 & & 0.68 & & 1.483 & 416 \\
\hline GINI & 40.179 & 11.798 & 23.000 & 29.300 & 35.450 & & 51.92 & & 61.330 & 367 \\
\hline$G D P P C$ & 22.946 & 19.621 & 0.709 & 4.152 & 27.483 & & 35.27 & & & 459 \\
\hline INFLATION & 9.8635 & 96.9 & -1.408 & 1.699 & 2.667 & & 6.47 & & 2075. & 459 \\
\hline EXPORTS & 5.8740 & 8.867 & -26.637 & 1.580 & 6.191 & & 10.83 & & 36.738 & 459 \\
\hline POPULATION & 76.789 & 241.029 & 0.405 & 5.398 & 10.446 & & 56.90 & & 1340.910 & 453 \\
\hline DEPEND & 54.613 & 9.111 & 36.041 & 48.466 & 52.006 & & 59.04 & & 92.825 & 459 \\
\hline CREDIT & 75.655 & 47.287 & 10.590 & 31.528 & 74.044 & & 104.81 & & 223.873 & 447 \\
\hline INTERNET & 29.669 & 28.859 & 0.0012 & 4.138 & 20.211 & & 51.53 & & 93.390 & 452 \\
\hline & & & & countries & & & & & & \\
\hline GDPPCG & 0.0338 & & -0.128 & 0.0134 & 0.039 & & 0.06 & & 0.153 & 306 \\
\hline$D E B T$ & 0.616 & 0.292 & 0.061 & 0.428 & 0.594 & & 0.76 & & 1.483 & 292 \\
\hline GINI & 32.808 & 7.444 & 23.000 & 27.633 & 30.900 & & 34.82 & & 53.950 & 227 \\
\hline$G D P P C$ & 32.889 & 16.723 & 4.587 & 27.483 & 33.159 & & 38.23 & & 87. & 306 \\
\hline INFLATION & 3.768 & & -0.494 & 1.621 & 2.205 & & 3.50 & & & 306 \\
\hline EXPORTS & 5.863 & 7.887 & -26.637 & 2.220 & 6.168 & & 10.52 & & 36.499 & 306 \\
\hline$P O P$ & 27.498 & 29.892 & 0.405 & 5.375 & 10.708 & & 56.99 & & 114.292 & 306 \\
\hline DEPEND & 51.122 & 4.544 & 43.835 & 47.827 & 49.912 & & 53.37 & & 68.944 & 306 \\
\hline CREDIT & 91.457 & 46.636 & 15.213 & 58.117 & 91.145 & & 115.62 & & 223.873 & 294 \\
\hline INTERNET & 39.080 & 30.133 & 0.0433 & 9.534 & 35.880 & & 68.82 & & 93.390 & 303 \\
\hline & & & No OEC & countries & & & & & & \\
\hline GDPPCG & $067 * * *$ & & -0.076 & 0.023 & & $* * *$ & 0.10 & & & 153 \\
\hline$D E B T$ & $0.380 * * *$ & 0.199 & 0.061 & 0.206 & 0.347 & $* * *$ & 0.54 & & 0.875 & 124 \\
\hline GINI & $52.131 * * *$ & 6.619 & 28.433 & 49.025 & 54.055 & $* * *$ & 56.72 & & 61.330 & 140 \\
\hline$G D P P C$ & $3.062 * * *$ & 1.373 & 0.709 & 1.576 & 3.173 & $* * *$ & 4.15 & & 6.296 & 153 \\
\hline INFLATION & $22.054 *$ & 167.353 & -1.408 & 3.490 & 6.925 & $* * *$ & 11.04 & & 2075.890 & 153 \\
\hline EXPORTS & 5.897 & & -20.633 & -0.434 & 6.314 & & 11.30 & & 36.738 & 153 \\
\hline$P O P$ & $179.396 * * *$ & 402.861 & 2.583 & 5.457 & 9.033 & & 44.45 & & 1340.910 & 147 \\
\hline DEPEND & $61.596 * * *$ & 11.623 & 36.041 & 54.051 & 60.678 & $* * *$ & 67.07 & & 92.825 & 153 \\
\hline CREDIT & $45.291 * * *$ & 30.946 & 10.590 & 24.278 & 32.270 & $* * *$ & 52.63 & & 129.503 & 153 \\
\hline INTERNET & $10.530 * * *$ & 11.617 & 0.001 & 0.786 & 6.555 & $* * *$ & 17.66 & & 40.650 & 149 \\
\hline
\end{tabular}

Notes: Period: 1994-2010. For country lists, see Table 1. (a) Mean-comparison test (2 tails); (b) Wilcoxon ranksum test.. ${ }^{* * *} \mathrm{p}<0.01,{ }^{* *} \mathrm{p}<0.05,{ }^{*} \mathrm{p}<0.10, \# \mathrm{p}<0.15$ 
The descriptive statistics of the dataset are shown in Table 3. We calculate the mean, standard deviation and reference distribution points for all the variables. We include the full dataset and further split it into two sub-samples, of OECD and non-OECD countries. We also run two univariate statistical hypothesis tests, the Wilcoxon signed rank test (Wilcoxon 1945) and the mean comparison test, in order to gain further insight into the variable distribution through the two sub-samples.

Firstly, we analyse the central tendency of the variables used in our full sample and compare it with the sub samples. The mean value for our interest variable $D E B T$, is 54 per cent; this is categorised as a medium debt level (Reinhart and Rogoff 2010). Further comparison between the mean levels in the subsamples shows considerable differences. OECD countries have an average $D E B T$ value equal to 61 per cent whereas the mean is 37 per cent for non-OECD countries. The statistical difference is evident through the mean comparison test showing a significant rejection $(\mathrm{p}<0.05)$ of the null hypothesis (HO: equal means). The implication is that there is a significant statistical difference between the values of the two subsamples. Our data accord with the theory suggesting that OECD countries on average have higher debt-to-GDP levels compared to non-OECD countries.

Further analysis of the means of our other interest variables within the dataset shows similar tendencies. Take GDP per capita growth rate (dependent variable) as an example. Within the full sample, the mean is 4 per cent. In the subsamples, the average rate of growth for OECD countries is around 3 per cent, in comparison to around 6 per cent in non-OECD countries . This substantial difference is explained by non-OECD countries being economically developing and therefore experiencing large increases in their economic growth rate. The significant difference is further evident through the mean comparison test.

To further stress the large differences in our subsamples, we also look at the median values of all the variables and run the Wilcoxon signed-rank test. As observed before, large differences are also seen across all variables when analysing their median values. For example, with the Gini index the median value of the full sample is 35.4 whereas for the subsamples it is 30.9 for OECD countries and 50.4 for non-OECD countries. A difference of 20.5 between subsamples together with the significant rejection (at the 5 per cent confidence level) of the null hypothesis of equal medians from the Wilcoxon signed-rank test, confirms a large statistical difference of income inequality between the subsamples.

Analysing the descriptive statistics for certain control variables may indicate patterns emerging between our dataset and our estimated results. Let us take POPULATION as an example. It shows a fairly low mean value (76.7), which could signify that our dataset as a whole includes countries with fairly low population levels. This may be reflected in the results of our regressions estimates as low population, in theory, would have a positive effect on economic growth. In contrast, Age dependency ratio displays a medium-high mean value (54.6 per cent), which may imply that the countries within our dataset have an ageing population. Theoretically this could be detrimental to economic growth as there 
are fewer people of working age supporting the potential increases in government expenditure on pensions through tax revenues.

It is clear from the descriptive statistics that there is a considerable difference between non-OECD countries and OECD countries. This difference could potentially be observed within our estimated results. We will address this specific issue in our robustness analysis.

\section{Results}

Table 4 presents the main results. The dependent variable is real GDP per capita growth, with the variable of interest being government debt as a ratio to GDP (Debt-to-GDP). Throughout all estimations, we control for INFLATION, EXPORTS, POPULATION,GDP PER CAPITA and AGE DEPENDENCY. We assume that governments systematically promote economic growth by reducing income inequality, with politically expensive fiscal reforms in the long run (10 years) and politically cheap sovereign debt in the middle run (5 years). ${ }^{9}$ The implication of this assumption is that sovereign debt can be zero if and only if income distribution is equal; otherwise the government would issue debt to foster economic growth through income inequality reduction. Empirically, it means that the GINI index impacts on growth only indirectly through the interaction with $D E B T$, but not directly. In equations $1-4$, we can imagine the GINI index as a control variable in CTRL with a coefficient constrained to zero. We shall relax this assumption in the robustness analysis.

The first column presents the benchmark specification using an OLS estimator. The impact of debt-to-GDP on GDP per capita growth is significant at the 5 per cent confidence interval, showing a negative linear relationship $(-0.70)$. On average a 1 per cent increase in debt-to-GDP will decrease GDP per capita growth by -0.7 per cent. This contradicts the present literature because it rejects both our HYP1 (positive relationship) and the alternative hypothesis of Ricardian Equivalence (insignificant relationship). However, it can be accounted for because the majority of countries within our dataset are OECD or middle-income countries. Therefore, they already have high debt-to-GDP levels, which could cause this negative impact on GDP per capita growth.

The results with respect to the control variables used in the benchmark equation, for the most part, are consistent with economic theory. The INFLATION coefficient shows a negative relationship with GDP per capita growth, as expected. INFLATION is a proxy for economic risk and so an increase in inflation leads to a decrease in growth. However, the coefficient itself is not significant. Individual coefficients of EXPORTS and POPULATION show highly significant, positive relationships with the dependent variable. For instance, as the population within a country increases, the overall level of production (and sometimes also productivity) in theory should increase, creating a positive change in GDP per capita growth. A similar understanding can explain the significant positive coefficient in EXPORTS i.e. an increase in a country's level of exports allows increases in GDP per capita growth. As for GDP per capita (in actual terms), our 
dataset yields a negative relationship with GDP per capita growth. This could once again come as a result of the majority of countries within our dataset being developed or middle-income. According to Barro (2000), developed countries find it more difficult to grow because they are closer to the steady state than developing countries. It accounts for the negative coefficient observed on GDP per capita. In order to account for biases such as country specific features, we

Table 4. Impact of debt-to-GDP ratio on 5-years economic growth.

\begin{tabular}{lccccc}
\hline Dependent Variable & Standard & Non Linear & $\begin{array}{c}\text { Heterog- } \\
\text { eneity }\end{array}$ & $\begin{array}{c}\text { Non-linear } \\
\text { heterog'ty }\end{array}$ \\
Per Capita GDP Growth & OLS & $F E$ & $F E$ & $F E$ & $F E$
\end{tabular}

Per Capita GDP Growth

$F E$
$(2)$

(3)

(4)

$(5)$

INTEREST VARIABLES

\begin{tabular}{|c|c|c|c|c|c|}
\hline$D E B T$ & $-0.7025^{* *}$ & $2.3297^{*}$ & $6.1404^{* *}$ & 3.3991\# & $16.9870^{* * *}$ \\
\hline$D E B T^{2}$ & & & $-3.1536^{*}$ & & $-12.5301^{* *}$ \\
\hline$D E B T^{*} G I N I$ & & & & -0.0238 & $-0.2527^{* *}$ \\
\hline$D E B T^{2} * G I N I$ & & & & & $0.2357^{*}$ \\
\hline \multicolumn{6}{|l|}{ CONTROLS } \\
\hline$G D P P C$ & $-0.0320 * * *$ & $-0.1627^{* * *}$ & $-0.1691^{* * *}$ & $-0.1609 * * *$ & $-0.1698^{* * *}$ \\
\hline INFLATION & -0.0108 & 0.0315 & $0.0343^{*}$ & 0.0319 & 0.0365\# \\
\hline EXPORTS & $0.0424^{* * *}$ & $0.0292^{* *}$ & $0.0286^{* *}$ & $0.0292 * *$ & $0.0271^{* *}$ \\
\hline POPULATION & $0.0020 * * *$ & -0.0023 & -0.0061 & -0.0020 & -0.0067 \\
\hline AGE DEPEND & $-0.0526 * * *$ & $-0.1623^{* * *}$ & $-0.1686^{* * *}$ & $-0.1603^{* * *}$ & $-0.1756^{* * *}$ \\
\hline CONSTANT & $5.5743^{* * *}$ & $13.0886^{* * *}$ & $12.9924^{* * *}$ & $12.8232^{* * *}$ & $13.0215^{\star * * *}$ \\
\hline Observations & 318 & 318 & 31 & 318 & 318 \\
\hline $\mathrm{R}^{2}$ & 0.355 & 0.315 & 0.329 & 0.316 & 0.347 \\
\hline FALL & 53.93 & 34.08 & 34.03 & 28.82 & 27.43 \\
\hline $\operatorname{Prob}\left(\mathrm{F}^{\mathrm{ALL}}\right)>\mathrm{F}$ & 0 & 0 & 0 & 0 & 0 \\
\hline FINT & 4.81 & 3.14 & 2.18 & 4.25 & 4.58 \\
\hline $\operatorname{Pr}\left(\mathrm{F}^{\mathrm{INT}}\right)>\mathrm{F}$ & 0.029 & 0.088 & 0.133 & 0.025 & 0.006 \\
\hline Likelihood-ratio & & 219.34 & 225.16 & 217.08 & 221.12 \\
\hline $\operatorname{Prob}(L R)<\operatorname{chi} 2$ & & 0 & 0 & 0 & 0 \\
\hline BPLM & & 159.2 & 153.2 & 147.4 & 114.2 \\
\hline $\operatorname{Pr}(\mathrm{BPLM})>\operatorname{chi} 2$ & & 0 & 0 & 0 & 0 \\
\hline $\mathrm{H}$ & & 101.3 & 27.80 & 52.68 & 74.02 \\
\hline $\operatorname{Pr}(\mathrm{H})>\operatorname{chi} 2$ & & 0 & 0.0002 & 0 & 0 \\
\hline Number of countries & & 27 & 27 & 27 & 27 \\
\hline \multicolumn{6}{|c|}{ 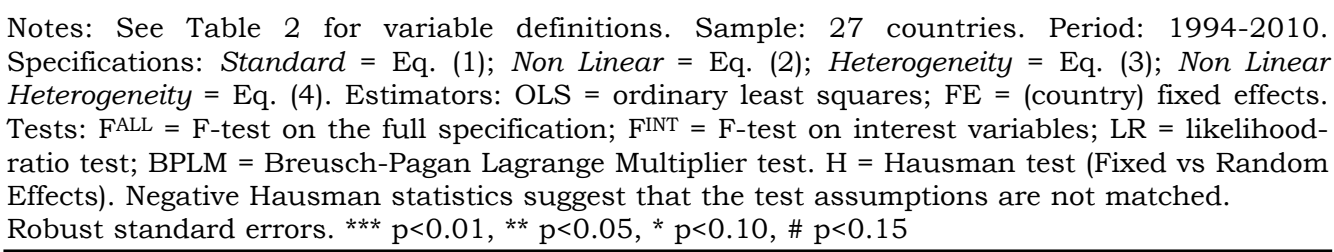 } \\
\hline
\end{tabular}


employ the likelihood ratio test to check if the use of $\mathrm{FE}$ is appropriate. The likelihood-ratio statistic does not reject the null hypothesis, confirming the suitability of FE (Column 2). Additionally, we use the Hausman test to check between FE and RE. The Hausman test statistic (101.3) rejects the null hypothesis at the 1 per cent significance level, thus confirming that $\mathrm{FE}$ is the most suitable approach for estimation (we do not report RE results, for brevity). The coefficient for debt-to-GDP becomes positive under FE. It is consistent with Ricardian Equivalence even if it is statistically significant only at the 10 per cent level. As for the control variables, exports, per capita GDP level and the age dependency ratio have the expected signs, are significant and remain stable through both $\mathrm{FE}$ and RE estimates.

The majority of the literature surrounding this topic finds a non-linear relationship between debt-to-GDP and GDP per capita growth. We test this hypothesis in Column 3, with the results for Equation 2 (Non-Linearity). The Hausman test rejects the null hypothesis in favour of FE (27.8). The adjusted $\mathrm{R}^{2}$ improves slightly with respect to the standard model. The most relevant observation noted by adopting this method is the sign on the coefficient for debt-to-GDP. It remains positive and, combining this with the negative sign on the non-linear term, draws an inverted-U-shape parabolic relationship between debt-to-GDP and GDP per capita growth. However, despite statistically significant linear and squared terms, the joint test is marginally insignificant, as the corresponding F-test on interest variables (2.18) accepts the null hypothesis (HO: $\beta=\gamma=0$ ). This indicates that the traditional quadratic specification does not work with our dataset and so does not corroborate our second hypothesis (HYP2) and the basis of most of the literature.

Given the lack of consistency with our results to the established quadratic model indicated by the previous literature we move to the Heterogeneity specification, where we introduce the Gini index as an interactive term. Column 4 presents FE results according to the Hausman test (32.72). Despite moving to a new specification, the $\mathrm{R}^{2}$ shows little deviation from the one recorded in our standard FE specification. The control variables are also fairly stable. The coefficient on $D E B T$ remains positive (3.39) and is marginally significant at a 15 per cent confidence interval. When we interact $D E B T$ with the Gini index, the related coefficient is negative (-0.02), but not significant. However, the significance of the joint F-test indicates that these variables have a joint influence on the level of GDP per capita growth (at the 5 per cent level) and so heterogeneity is present. This indicates that the subsequent relationship between GDP per capita growth and debt-to-GDP is positive, but the slope changes according to country specific levels of income inequality. The estimated results under this specification corroborate weakly our third hypothesis (HYP3).

The results from the previous two specifications produce mixed results: the quadratic (non-linear) relationship is significant individually but not jointly, whereas there is a weak heterogeneous relationship. Therefore, within our final specification, we combine the two models to test whether the heteroge- 
neous relationship is actually non-linear, rather than linear. We run the Hausman test which, once again, rejects the null hypothesis, signifying FE as the appropriate method. The results of our Equation (4) are presented in Column 5. The adjusted $\mathrm{R}^{2}$ increases not only with respect to the standard model, but also the other advanced specifications used. Analysing our variables of interest, we see that the coefficient on $D E B T$ becomes highly significant and positive (16.99) and the coefficient on $D E B T^{2}$ becoming significantly negative $(-12.5)$, suggesting a significant non-linear relationship. Testing the joint influence of our interest variable yields the F-statistic to be significant at the 1 per cent confidence interval. This means that there is a quadratic relationship between GDP per capita growth and debt-to-GDP, and that a country's specific level of income inequality creates differences in the shape of this relationship. Therefore, we would observe the formation of different parabolas.

In order to understand this result, we plot the relationship between GDP per capita and debt-to-GDP of two representative countries. We compare Finland as representative of countries with a fairly low level of Gini, with Chile as our representative of a country with a fairly high level of Gini. The relationship is shown in Figure 2. Let us consider the shape of the relationships first. Given Chile's average Gini level to be approximately 42.2, the corresponding relationship shows a flatter inverted U-shape parabola. Finland, in comparison, has a lower average Gini level of approximately 25.8; and so a much steeper inverted U-shape parabola is observed. Finland and Chile display two different parabolic relationships, revealing that the non-linear relationship between GDP per capita and debt-to-GDP ratio is heterogeneous. Consequently, as our hypothesis HYP4 suggests, each country, depending on its level of income inequality, will have a different threshold level of debt. This becomes apparent within this graph. Finland's threshold debt level is approximately 81 per cent whereas Chile has a much higher threshold debt level of 124 per cent.

As we cannot address causality issues fully, given data availability limitations, we assume that in the short run, income inequality that is persistent and, hence, similar to previous values, affects growth to a greater extent than the latter determines the former. In this sense, we can look at this graph as a causal relationship. Countries that suffer from high levels of income inequality (higher Gini levels) are more likely to benefit from higher growth levels as they become increasingly indebted because their debt threshold point is very high. This is made clear from Chile's debt to growth relationship forming a faint inverted U-shaped parabola. Contrastingly, countries like Finland that have low levels of income inequality will display a far steeper inverted U-shape relationship with a much lower debt threshold point. This indicates that low Gini bearing countries also benefit from higher growth levels as they become more indebted, but the point where any further indebtedness will lead to a negative impact on economic growth is much lower. 
Figure 2. Heterogeneous Non-Linear Growth-Debt Nexus: 5-years growth

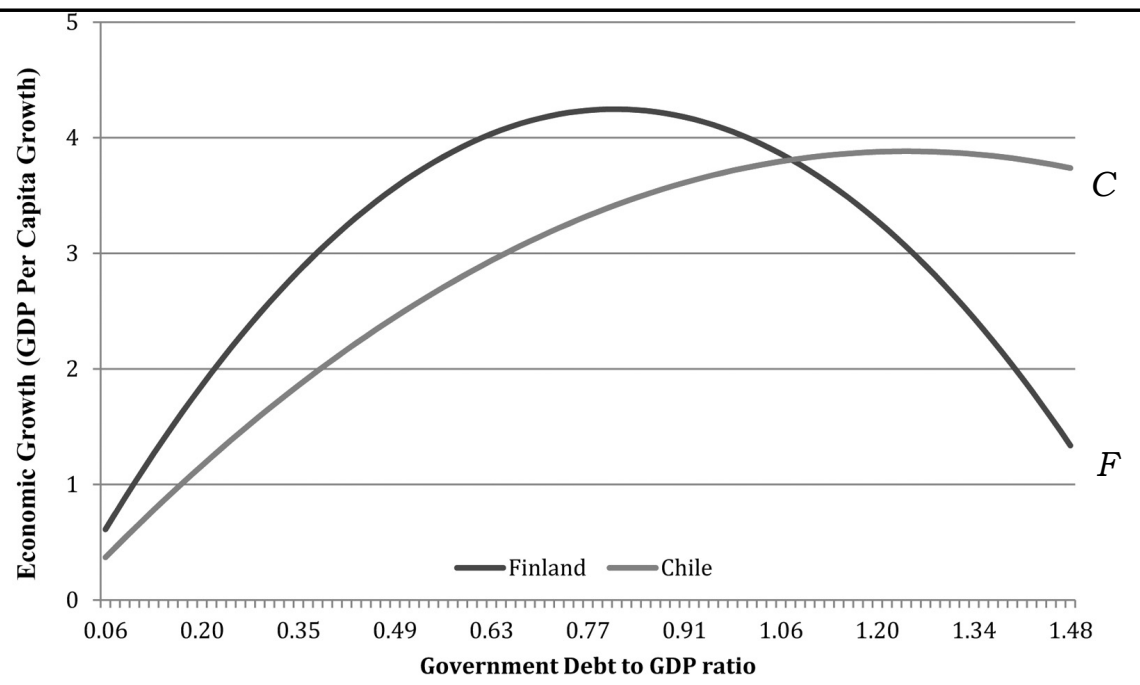

Notes: Curves derived from the estimated coefficients of separated and interactive $D E B T$ variables reported in Column 5 of Table 4. Average Gini is 25.8 for Finland and 42.5 for Chile. The turning point is a debt-to-GDP ratio equal to 81 per cent for Finland and 124 per cent for Chile.

In summary, because of the presence of two different inverted U-shaped parabolas, a 1 per cent increase in debt-to-GDP would produce different effects on different countries, depending on their level of inequality. This corroborates our hypothesis HYP4.

\section{ROBUSTNESS}

We carry out six different robustness exercises to check the plausibility of our findings. In the first, we relax the assumption that sovereign debt can be zero if and only if income distribution is equal and we rerun all the specifications adding Gini index separately; see Table 5. Test statistics are, mostly, similar to those in Table 4, but we report $\mathrm{FE}$ according to the Hausman test in Columns 4 and 5 and for comparison reasons in Column 2 and 3 as Hausman test statistics are negative. ${ }^{10}$ Standard estimates are similar to previous results, whereas the higher absolute values of $D E B T$ coefficients and the significant joint $\mathrm{F}$-test on the interest variables in Column 3 suggest a stronger non-linearity than in Table 4. DEBT and $D E B T * G I N I$ coefficients switch in sign and significance in Column 4. It is possible that they are capturing the more intense quadratic growth-debt relationship. In Column 5, we find not only a heterogeneous inverted U-shaped relationship, but also stronger evidence that the turning point in the growth-debt relationship increases with the income inequality. 
Table 5. Impact of debt-to-GDP ratio on 5-years economic growth with separated Gini control variable

\begin{tabular}{|c|c|c|c|c|c|}
\hline Dependent Variable & \multicolumn{2}{|c|}{ Standard } & Non Linear & $\begin{array}{l}\text { Heterog- } \\
\text { eneity }\end{array}$ & $\begin{array}{l}\text { Non-linear } \\
\text { heterog'ty }\end{array}$ \\
\hline Per Capita GDP Growth & $\begin{array}{l}\text { OLS } \\
\text { (1) }\end{array}$ & $\begin{array}{l}F E \\
(2)\end{array}$ & $\begin{array}{l}F E \\
(3)\end{array}$ & $\begin{array}{l}F E \\
(4)\end{array}$ & $\begin{array}{c}F E \\
(5)\end{array}$ \\
\hline \multicolumn{6}{|l|}{ INTEREST VARIABLES } \\
\hline$D E B T$ & $-0.6876^{* *}$ & $3.0110^{* *}$ & $8.7358 * * *$ & $-4.8682 *$ & $16.4806^{*}$ \\
\hline$D E B T^{2}$ & & & $-4.6021^{* * *}$ & & $-19.4267 \#$ \\
\hline$D E B T^{*} G I N I$ & & & & $0.1880^{* *}$ & $-0.2663^{* *}$ \\
\hline$D E B T^{2}{ }^{*} G I N I$ & & & & & $0.4195^{* *}$ \\
\hline \multicolumn{6}{|l|}{ CONTROLS } \\
\hline GINI & -0.0057 & $-0.0623^{*}$ & $-0.0759 * *$ & $-0.1426^{* * *}$ & $-0.1907^{* * *}$ \\
\hline$G D P P C$ & $-0.0358 * * *$ & $-0.1691^{* * *}$ & $-0.1750 * * *$ & $-0.1770 * * *$ & $-0.1744^{* * *}$ \\
\hline INFLATION & -0.0083 & $0.0367^{*}$ & $0.0409 * *$ & $0.0386^{*}$ & $0.0437^{* * *}$ \\
\hline EXPORTS & $0.0398^{* * *}$ & $0.0205^{*}$ & $0.0197^{*}$ & $0.0193^{*}$ & 0.0199* \\
\hline POPULATION & $0.0022^{* * *}$ & 0.0076 & 0.0030 & $0.0138 \#$ & $0.0146^{*}$ \\
\hline$A G E D E P E N D$ & $-0.0526^{* * *}$ & $-0.1481^{* *}$ & $-0.1540 * * *$ & $-0.1581^{* * *}$ & $-0.1487^{* * *}$ \\
\hline CONSTANT & $5.9351^{* * *}$ & $13.8516^{* * *}$ & $13.7969 * * *$ & $17.6650^{* * *}$ & $17.8165^{* * *}$ \\
\hline Observations & 306 & 306 & 306 & 306 & 306 \\
\hline $\mathrm{R}^{2}$ & 0.387 & 0.395 & 0.427 & 0.429 & 0.457 \\
\hline$F^{A L L}$ & 41.71 & 36.55 & 45.09 & 37.01 & 81.67 \\
\hline $\operatorname{Prob}\left(F^{A L L}\right)>F$ & 0 & 0 & 0 & 0 & 0 \\
\hline FINT & 4.53 & 5.76 & 7.12 & 5.40 & 4.73 \\
\hline $\operatorname{Pr}\left(\mathrm{F}^{\mathrm{INT}}\right)>\mathrm{F}$ & 0.034 & 0.024 & 0.003 & 0.011 & 0.075 \\
\hline Likelihood-ratio & & 279.47 & 295.75 & 266.84 & 269.38 \\
\hline $\operatorname{Prob}(\mathrm{LR})<\operatorname{chi} 2$ & & 0 & 0 & 0 & 0 \\
\hline BPLM & & 226.7 & 219.2 & 195.9 & 175.6 \\
\hline $\operatorname{Pr}(\mathrm{BPLM})>\mathrm{chi} 2$ & & 0 & 0 & 0 & 0 \\
\hline $\mathrm{H}$ & & -487.8 & -169.3 & 69.50 & 17.68 \\
\hline $\operatorname{Pr}(\mathrm{H})>\operatorname{chi} 2$ & & 1 & 1 & 0 & 0.0605 \\
\hline Number of countries & & 27 & 27 & 27 & 27 \\
\hline
\end{tabular}

Notes: See Table 2 for variable definitions. Sample: 27 countries. Period: 1994-2010. Specifications: Standard $=$ Eq. (1); Non Linear = Eq. (2); Heterogeneity $=$ Eq. (3); Non Linear Heterogeneity $=$ Eq. (4). Estimators: OLS = ordinary least squares; $\mathrm{FE}=$ (country) fixed effects. Tests: $F^{A L L}=$ F-test on the full specification; $F^{I N T}=$ F-test on interest variables; $L R=$ likelihoodratio test; BPLM = Breusch-Pagan Lagrange Multiplier test. $\mathrm{H}=$ Hausman test (Fixed vs Random Effects). Negative Hausman statistics suggest that the test assumptions are not matched.

Robust standard errors. ${ }^{* * *} \mathrm{p}<0.01,{ }^{* *} \mathrm{p}<0.05,{ }^{*} \mathrm{p}<0.10, \# \mathrm{p}<0.15$ 
Figure 3 shows the results for our two reference countries, Finland and Chile: the positive impact of debt on growth turns negative at 56 per cent debtto-GDP ratio for Finland, whereas the turning point is out of the represented range for Chile.

Figure 3. Heterogeneous Non-Linear Growth-Debt Nexus: 5-years growth with Gini control

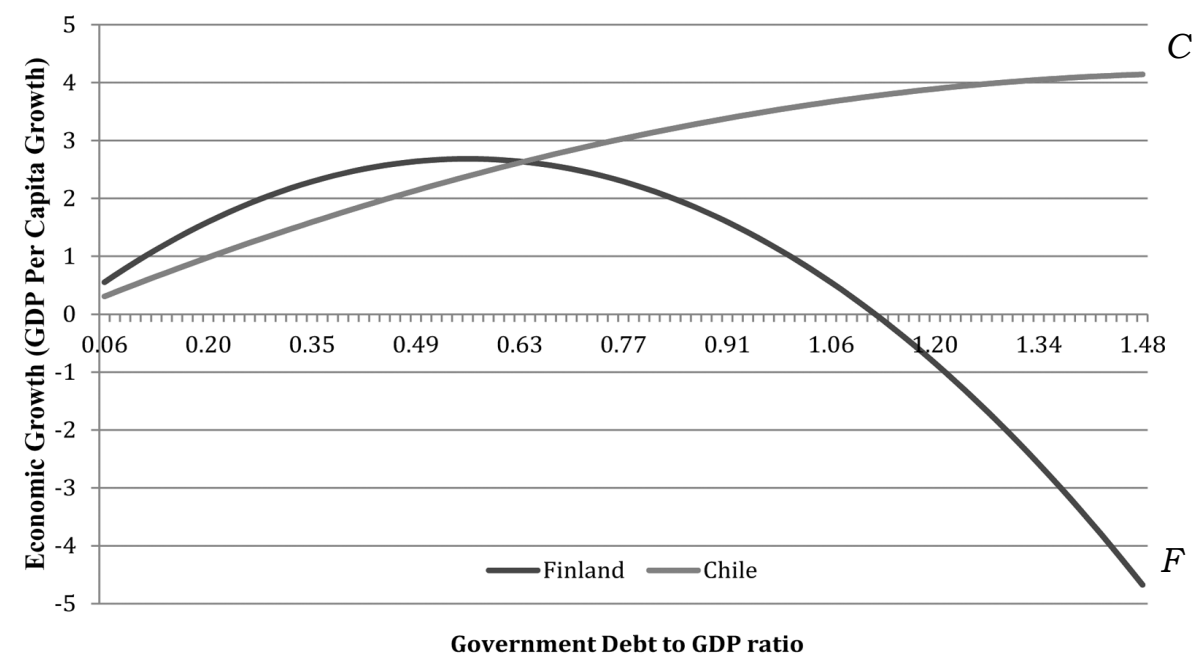

Notes: Curves derived from the estimated coefficients of separated and interactive DEBT variables reported in Column 5 of Table 5. Average Gini is 25.8 for Finland and 42.5 for Chile. The turning point is a debt-to-GDP ratio equal to 56 per cent for Finland and more than the maximum value (148 per cent) for Chile.

The second exercise tests the robustness of our results to a shorter growth rate period, using the 3 year growth rate as the dependent variable. Again we prefer $\mathrm{FE}$ to $\mathrm{RE}$ according to the Hausman test. Estimates presented in Table 6 corroborate fully our previous results observed in Table 4 . We find weak evidence for growth-debt non-linearity in Column 3 and for growth-debt heterogeneity in Column 4, but stronger support for a heterogeneous non-linear relationship in Column 5 .

Figure 4 draws the growth-debt relationship for Finland and Chile identifying, respectively, 77 per cent and 134 per cent as turning points. These findings reveal that the impact of income inequality on the growth-debt relationship is quite immediate and persistent.

For the other four robustness exercises, we use the FE non-linearity heterogeneity specification as benchmark. Tables 7 reports the third and fourth robustness checks. We begin by modifying our benchmark specification. Columns 1-5 report the separate removal of some control variables in order to test the sensitivity of our results to different specifications. The results are conclusive and indicate that the separate removal of each control variable creates little change on the significance and the signs of the coeffi- 
cients on our variable of interest, with respect to our benchmark specification (Column 6). The only exception is Column 1 in which we removed GDPPC, a core variable for a growth regression model: interactive terms are significant jointly, but not individually. Hence, overall, this exercise confirms our main findings.

Table 6. Impact of debt-to-GDP ratio on 3-years economic growth.

\begin{tabular}{|c|c|c|c|c|c|}
\hline Dependent Variable & \multicolumn{2}{|c|}{ Standard } & \multirow{2}{*}{$\begin{array}{l}\text { Non Linear } \\
\qquad \begin{array}{c}F E \\
\text { (3) }\end{array}\end{array}$} & \multirow{2}{*}{$\begin{array}{l}\text { Heterog- } \\
\text { eneity } \\
F E \\
\text { (4) }\end{array}$} & \multirow{2}{*}{$\begin{array}{l}\text { Non-linear } \\
\text { heterog'ty } \\
\text { FE } \\
\text { (5) }\end{array}$} \\
\hline Per Capita GDP Growth & $\begin{array}{l}\text { OLS } \\
\text { (1) }\end{array}$ & $\begin{array}{l}F E \\
(2)\end{array}$ & & & \\
\hline \multicolumn{6}{|l|}{ INTEREST VARIABLES } \\
\hline$D E B T$ & $-0.9646^{* *}$ & 2.0690 & 5.7804 & 4.9390\# & $22.9012^{* * *}$ \\
\hline$D E B T^{2}$ & & & -3.0983 & & $-17.4315^{* *}$ \\
\hline$D E B T^{*} G I N I$ & & & & -0.0632 & $-0.3926^{* *}$ \\
\hline$D E B T^{2}{ }^{*} G I N I$ & & & & & $0.3555^{* *}$ \\
\hline \multicolumn{6}{|l|}{ CONTROLS } \\
\hline$G D P P C$ & $-0.0435^{* * *}$ & $-0.2275^{* * *}$ & $-0.2350^{* * *}$ & $-0.2226^{* * *}$ & $-0.2361^{* * *}$ \\
\hline INFLATION & -0.0188 & 0.0485 & $0.0513^{*}$ & 0.0495 & 0.0551\# \\
\hline EXPORTS & $0.0474 * * *$ & $0.0286^{* *}$ & $0.0281^{* *}$ & $0.0284 * *$ & $0.0254^{*}$ \\
\hline POPULATION & $0.0028 * * *$ & 0.0025 & -0.0014 & 0.0033 & -0.0019 \\
\hline AGE DEPEND & $-0.0732 * * *$ & $-0.1935^{* *}$ & $-0.2011^{* * *}$ & $-0.1869 * *$ & $-0.2073^{* * *}$ \\
\hline CONSTANT & $7.7149 * * *$ & $16.5802^{* * *}$ & $16.6108 * * *$ & $15.7905^{* * *}$ & $16.3142^{* * *}$ \\
\hline Observations & 328 & 328 & 328 & 328 & 328 \\
\hline $\mathrm{R}^{2}$ & 0.299 & 0.202 & 0.207 & 0.204 & 0.224 \\
\hline$F^{A L L}$ & 39.23 & 26.02 & 21.99 & 20.80 & 20.69 \\
\hline $\operatorname{Prob}\left(F^{A L L}\right)>F$ & 0 & 0 & 0 & 0 & 0 \\
\hline FINT & 4.330 & 1.070 & 0.860 & 2.740 & 4.450 \\
\hline $\operatorname{Pr}\left(\mathrm{F}^{I N T}\right)>\mathrm{F}$ & 0.0380 & 0.311 & 0.436 & 0.0830 & 0.00700 \\
\hline Likelihood-ratio & & 147.66 & 149.67 & 147.74 & 147.15 \\
\hline $\operatorname{Prob}(\mathrm{LR})<\operatorname{chi} 2$ & & 0 & 0 & 0 & 0 \\
\hline BPLM & & 82.49 & 81.22 & 76.84 & 58.74 \\
\hline $\operatorname{Pr}(\mathrm{BPLM})>\operatorname{chi} 2$ & & 0 & 0 & 0 & 0 \\
\hline $\mathrm{H}$ & & 46.60 & -30.88 & 32.72 & 45.11 \\
\hline $\operatorname{Pr}(\mathrm{H})>\operatorname{chi} 2$ & & 0 & 1 & 0 & 0 \\
\hline Number of countries & & 27 & 27 & 27 & 27 \\
\hline
\end{tabular}

Notes: See Table 2 for variable definitions. Sample: 27 countries. Period: 1994-2010. Specifications: Standard $=$ Eq. (1); Non Linear = Eq. (2); Heterogeneity $=$ Eq. (3); Non Linear Heterogeneity $=$ Eq. (4). Estimators: OLS = ordinary least squares; FE = (country) fixed effects. Tests: $F^{A L L}=$ F-test on the full specification; $F^{I N T}=$ F-test on interest variables; $L R=$ likelihoodratio test; BPLM = Breusch-Pagan Lagrange Multiplier test. $\mathrm{H}=$ Hausman test (Fixed vs Random Effects). Negative Hausman statistics suggest that the test assumptions are not matched.

Robust standard errors. ${ }^{* * *} \mathrm{p}<0.01,{ }^{* *} \mathrm{p}<0.05,{ }^{*} \mathrm{p}<0.10$, \# $\mathrm{p}<0.15$ 
Figure 4. Heterogeneous Non-Linear Growth-Debt Nexus: 3-years growth

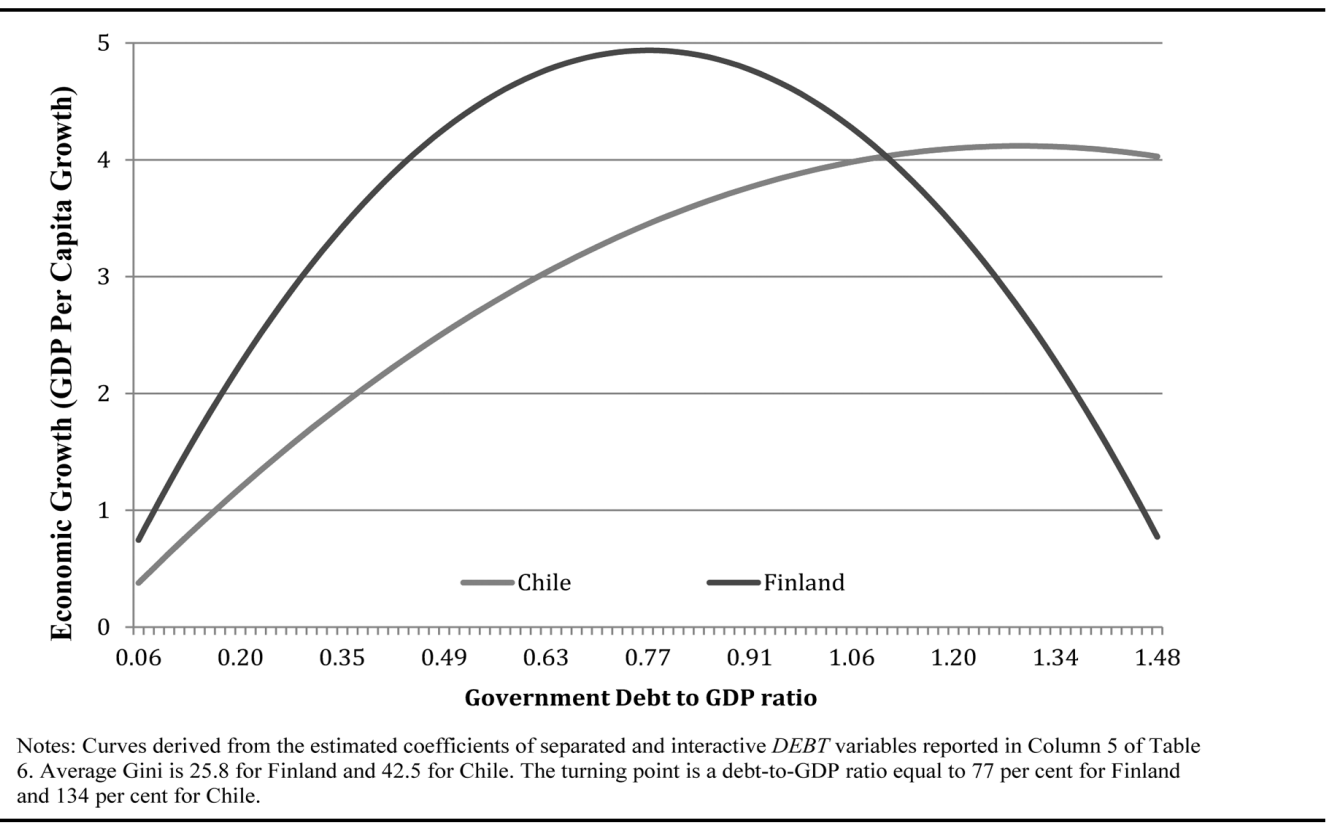

In Columns 7-8, we control for potential omitted variables by adding extra regressors to our specification. In accordance with growth theory (see Pagano 1993), proxies used for financial development such as domestic credit to the private sector could potentially have a positive effect on economic growth. In column 7 we introduce CREDIT (expressed as per cent of GDP). The t-statistic and its corresponding $\mathrm{p}$-value suggest that it is insignificant. Moreover, the negative sign on the coefficient conflicts with economic theory, as Pagano (1993) suggests increases in financial development leads to a positive effect on economic growth. Therefore, this indicates that CREDIT as a variable lacks relevant influencing power. All previous results on our variables of interest are fully corroborated.

We introduce a popular variable used in empirical studies, INTERNET (Internet users per 100 people), as a proxy for technological progress. We include this as an extra control variable in Column 8. However, the t-statistic and corresponding $\mathrm{p}$-value indicate that the variable is not significant and so has no effect on the coefficients of our focus variables as they remain consistent with our benchmark specification (Column 6). The only exception is $D E B T^{2}$ * GINI that is marginally insignificant at 10 per cent level individually, but significant at 1 per cent in the joint test FINT. Modifications to the benchmark specification indicate that the coefficients show little deviation from our main results. The joint hypothesis test of our interest variables always rejects the null hypothesis throughout all robustness exercises in Table 7. 


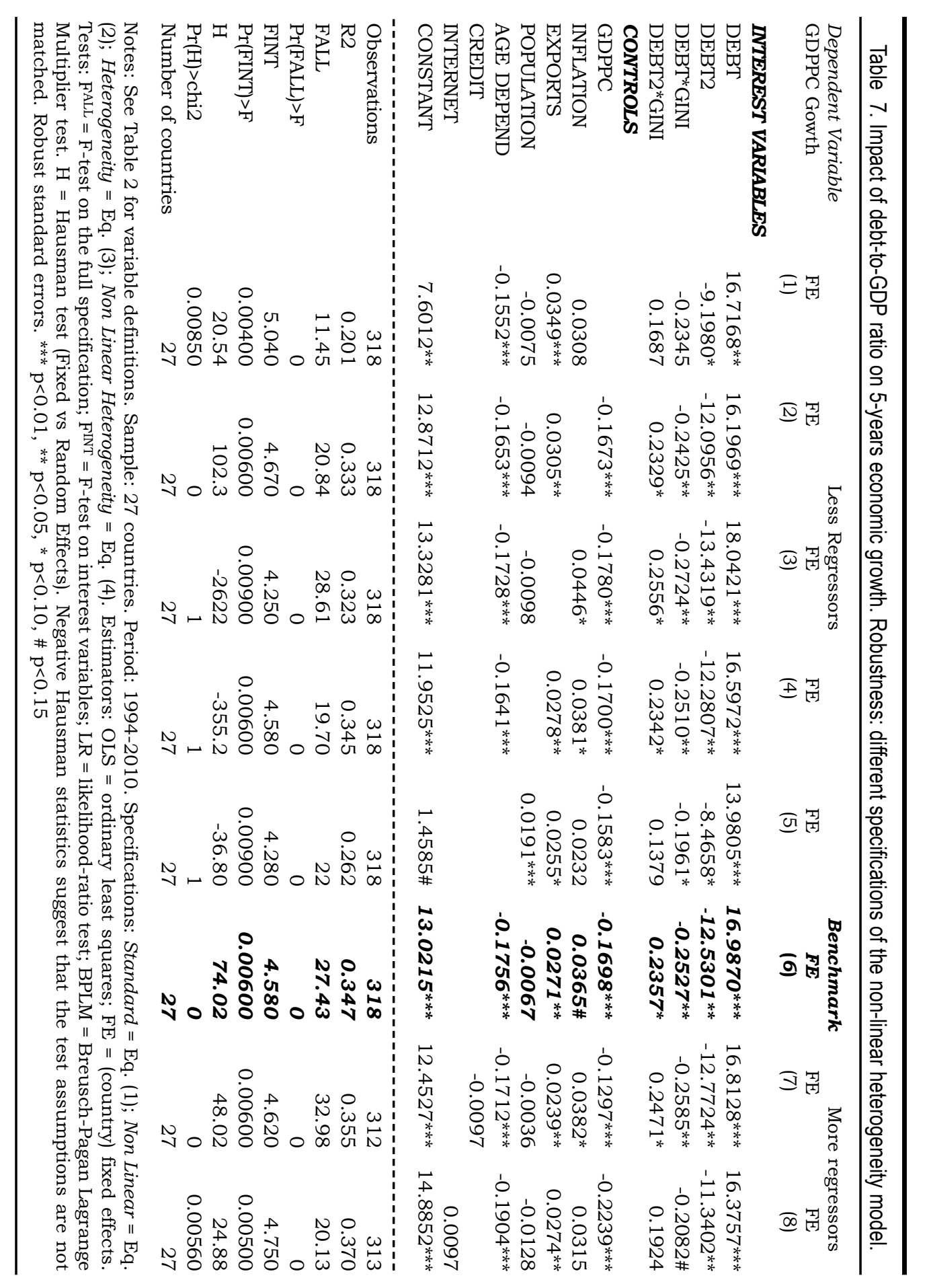


This, therefore, indicates that our variables of interest always hold influencing power, regardless of the inclusion of more or fewer control variables. This further confirms the structural robustness of our results.

Table 8 presents the results of two further robustness checks. The first column presents the benchmark specification for the whole period. Column 2 reports the results over the shorter time period, spanning 1994-2006. This period excludes both the subprime mortgage crisis that began in the early months of 2007 within the US; and the onset of the Eurozone debt crisis, in which several peripheral European countries, notably Greece, Spain, Ireland, Italy and Portugal, experienced very high debt-to-GDP levels (Young and Semmler 2011). In particular, we exclude the subprime crisis because one of its many consequences was the increase in government debt levels in many developed countries. These occurred as a result of governments being forced to rescue failing banks through financial packages such as capital injections and liquidity provisions. $\mathrm{T}$ It left many governments unable to finance their own debts and so debt accumulation occurred (Ureche-Rangau and Burietz 2013). With this exercise, we check if our non-linear heterogeneous relationship is driven by such crises.

Our results are not affected by the 2007-2009 subprime mortgage crisis and the 2009-2012 sovereign debt crisis. Table 8 shows a further decrease in the number of observations from 328 in the benchmark (Column 1) to 279 within the 1994-2006 sub-period (Column 2). However, the coefficient estimates on our variable of interest are very stable. For consistency with previous estimates, we present FE estimates also when the Hausman test produces negative (unreliable) test statistics. A majority of our variables of interest are highly significant, with $D E B T^{2}$ experiencing an increase from a 5 per cent to a 1 per cent confidence interval, and $D E B T^{2}{ }^{*}$ GINI from a 10 per cent to a 1 per cent confidence interval. Additionally, our control variables also remain largely unchanged. This provides evidence that our results are robust to the exclusion of subprime crisis period and Eurozone debt crisis period. In brief, the subprime mortgage and the debt crisis are not driving our findings.

As final robustness checks, we split our data into two separate subsamples, one displaying the estimates for OECD countries (Column 3) and the other for non-OECD countries (Column 4). Concentrating on the OECD sub sample, the number of observations falls to 210 , indicating that the majority of our dataset consists of OECD countries. The signs on the estimated coefficients on our variables of interest stay in line with our benchmark results. Additionally, the significance level improves slightly within the OECD sub-sample, as all variables of interest now become significant at the 1 per cent confidence interval. This indicates that our results become more robust when we consider more homogeneous countries, an assumption that works against our main hypothesis (HYP4). Upon moving to the non-OECD sub-sample, the lack of significance may be linked to the low number of observations. However, the signs on the coefficients for the most part remain unchanged. 
Table 8. Impact of debt-to-GDP ratio on 5-years economic growth. Robustness: different subsamples.

Model
Sample
Estimator
Period

INTEREST VARIABLES

\begin{tabular}{|c|c|c|c|c|}
\hline$D E B T$ & $16.9870^{* * *}$ & $16.4809^{* * *}$ & $11.1943^{* * *}$ & $55.8245^{*}$ \\
\hline$D E B T^{2}$ & $-12.5301^{* *}$ & $-11.7136^{* * *}$ & $-8.9275^{* * *}$ & -40.6298 \\
\hline$D E B T^{*} G I N I$ & $-0.2527 * *$ & $-0.2521^{* *}$ & $-0.3218^{* * *}$ & -0.8496 \\
\hline$D E B T^{2} * G I N I$ & $0.2357^{*}$ & $0.2503^{* * *}$ & $0.2701^{* * *}$ & 0.6900 \\
\hline \multicolumn{5}{|l|}{ CONTROLS } \\
\hline$G D P P C$ & $-0.1698 * * *$ & $-0.1043^{* * *}$ & $-0.1669 * * *$ & 0.1548 \\
\hline INFLATION & 0.0365\# & $0.0402^{*}$ & -0.0099 & $0.0360 \#$ \\
\hline EXPORTS & $0.0271^{* *}$ & $0.0196^{*}$ & 0.0030 & $0.0310 *$ \\
\hline POPULATION & -0.0067 & -0.0030 & $-0.1719^{*}$ & $-0.0210 \#$ \\
\hline$A G E D E P E N D$ & $-0.1756^{* * *}$ & $-0.2106^{* * *}$ & -0.0778 & $-0.1962^{* * *}$ \\
\hline CONSTANT & $13.0215^{* * *}$ & $12.9066^{* * *}$ & $15.8342^{*}$ & $14.1558 * * *$ \\
\hline Observations & 318 & 279 & 210 & 108 \\
\hline $\mathrm{R}^{2}$ & 0.347 & 0.364 & 0.445 & 0.445 \\
\hline FALL & 27.43 & 35.07 & 51.94 & 979.4 \\
\hline $\operatorname{Prob}\left(\mathrm{F}^{A L L}\right)>\mathrm{F}$ & 0 & 0 & 0 & 0 \\
\hline FINT & 4.580 & 8.680 & 6.580 & 11.92 \\
\hline $\operatorname{Pr}\left(\mathrm{F}^{\mathrm{INT}}\right)>\mathrm{F}$ & 0.00600 & 0 & 0.00200 & 0.00200 \\
\hline $\mathrm{H}$ & 74.02 & 279.8 & 239.0 & -4.990 \\
\hline $\operatorname{Pr}(\mathrm{H})>\operatorname{chi} 2$ & 0 & 0 & 0 & 1 \\
\hline Number of countries & 27 & 27 & 18 & 9 \\
\hline
\end{tabular}

In summary, our main findings of a non-linear heterogeneous relationship are robust through various econometric exercises. They include the individual removal of control variables in order to test the structural validity of our specification, the addition of extra control variables to test for omitted variable bias, and sub-period and sub-sample regressions to check the robustness to particular exceptional events or more unstable countries. 


\section{CONCLUDING REMARKS}

The lasting effect of the recent crisis has put a great strain on many global economies. As a consequence, governments have opted to exercise budget deficits in order to bailout the financial system, and/or to employ fiscal stimulus packages. In an attempt to stabilise their individual economies after the recent crisis, many governments financed huge budget deficits and in turn accumulated government debt. The majority of literature points towards a non-linear inverted U-shaped relationship between sovereign debt and economic growth. However, upon analysing the empirical literature, there are mixed results in what is considered the precise threshold level of debt. Analogous to the debt-growth nexus, the well-known Williamson-Kuznets' hypothesis of an inverted-U shaped relationship between income inequality and economic development also has an ambiguous effect on economic growth, depending on growth convergence.

In this paper, we combine the two puzzles and hypothesise a non-linear heterogeneous relationship between government debt and economic growth as the reason for mixed results on the finance-growth nexus. This suggests that there is an inverted U-shaped relationship, but that it varies in accordance to a country's specific level of income inequality, as measured by the Gini index. The presence of a non-linear heterogeneous relationship also implies that a country's threshold point is different, depending on its income inequality level.

In order to test our hypothesis, we examined systematically several different types of relationship between sovereign debt and economic growth, as explored in the literature. Results from the linear model indicate an insignificant relationship. We also tested the non-linear relationship and despite our results showing a positive coefficient on $D E B T$ and a negative coefficient $D E B T^{2}$, the variables of interest are individually significant but jointly (marginally) insignificant, thus indicating a weak non-linear relationship. When we interact $D E B T$ with Gini index, a significant joint $F$-test indicates the presence of a heterogeneous linear relationship. Due to the mixed results of the previous two specifications, we moved to test a non-linear heterogeneous relationship that fully support our new hypothesis of an heterogeneous inverted Ushaped relationship between sovereign debt and economic growth according to the level of income inequality. We find that countries with a lower Gini index show a more intense debt-growth relationship, but a lower threshold point.

The main policy implication of our results is that the notion of a 'golden' threshold level of debt applicable to every country does not exist, because individual country specific circumstances (such as income inequality) play a pivotal role in the way sovereign debt interacts with economic growth. As a consequence, governments exercising homogenous fiscal policies, as part of international austerity policy programmes such as in the European Union, may have undesired outcomes depending on a country's income inequality level. In general, countries with fairer income distributions grow more when 
they are ruled by more fiscally virtuous governments whereas countries with less equal income distributions can bear higher levels of sovereign debt.

Our findings could be improved further. Firstly, we were presented with a number of limitations with respect to the availability of data. The lack of available data concerning the Gini index has reduced the number of countries within our dataset. In the same vein, our econometric analysis is dependent on a fairly small number of years. Future research may benefit from looking at a longer time period. In particular, we could remove the assumption that debt affects growth and test explicitly the causality nexus addressing the endogeneity problem. Additionally, more advanced econometric analysis could be used to identify the presence of a non-linear heterogeneous relationship rather than relying on the simple use of interaction terms. This may therefore lead to a more precise measure of the relationship. Another extension could be the application of different proxies for income inequality to check the impact of the taxation system on our results. We hope our analysis leads the way to a more nuanced investigation of these critical economic relationships.

Accepted for publication: 10th August 2015

\section{ENDNOTES}

1. F Marchionne, Indiana University, Kelley School of Business, Bloomington, Indiana 47405, USA; Money and Finance Research Group (MoFiR), Ancona, Italy; fmarchio@indiana.edu. S. Parekh, University of Birmingham; sunnyparekh06@gmail.com.

2. Similar exercises are applied to other financial indicators. For example, the threshold values for credit to private sector; liquid liabilities and domestic credit are 94 per cent, 97 per cent and 100 per cent respectively (Law and Singh 2014).

3. See Barajas et al (2013) for other dimensions of potential heterogeneity.

4. The main theories on the growth-inequality nexus are credit-market imperfections, political economy, social unrest, and saving rates. Their empirical predictions are ambiguous and empirical results very weak. However, Barro's (2008) results could be interpreted in favour of the credit-market imperfections theory.

5. Age dependency ratio is the ratio between the population and those that are dependent on others (i.e. the elderly and the working age) (Bongaarts 2002).

6. The null hypothesis of the Hausman test is that that fixed and random effects are not statistically different (Gujarati 2004). The Breusch Pagan Lagrange Multiplier Test has the null hypothesis that there is zero variance amongst country effects, whereas the null hypothesis of the likelihood-ratio test is that country effects are jointly equal to zero (Wooldridge 2009).

7. Inflation is measured as annual percentage change, Exports as a percentage share of GDP, Population is in millions and GDP per capita in real terms. 
8. The Gini Index has a scale of 1-100 where, the closer to 1 a country is, the more equal the distribution of income, and the closer to 100 the more unequal the level of income distribution (Yitzhaki 1979).

9. Recent pension reforms are a typical example of this pattern. They have reduced income inequality among workers with similar contributive history. But, the overall pension expenditure will increase in the medium term, because of the generous transition rules necessary to approve pension reforms (e.g. Italy).

10. Negative Hausman test statistics are common in small samples where the asymptotic assumptions of the test are not met. Schreiber (2008) shows that not only can negative statistics not be considered equal to zero because, in this case, the whole Hausman test is unreliable. Moreover, the Hausman test could produce biased positive statistics in small samples.

\section{REFERENCES}

Aizenman, J, Kletzer K and Pinto B (2007) 'Economic Growth with Constraints on Tax Revenues and Public Debt: Implications for Fiscal Policy and Cross-Country Differences', NBER WP 12750, National Bureau of Economic Research, Cambridge MA.

Arcand J L, Berkes E and Panizza U (2012) 'Too Much Finance?', IMF Working Paper 12/161, International Monetary Fund, Washington DC.

Aschauer D (2000) 'Do states optimize? Public capital and economic growth', The Annals of Regional Science, 34(3), 343-363.

Banerjee A V, and Duflo E (2003) 'Inequality And Growth: What Can The Data Say?', Journal of Economic Growth, 8(3), 267-299.

Barajas A, Chami R and Yousefi S R (2013) 'The finance and growth nexus re-examined: do all countries benefit equally?', IMF Working Paper 13/130, International Monetary Fund, Washington DC.

Barro R (1974) 'Are government bonds net wealth?', Journal of Political Economy, 82(6), 1095-1117.

Barro R (1996) 'Determinants of economic growth: a cross-country empirical study', NBER Working Paper Series No.5696, National Bureau of Economic Research, Cambridge MA.

Barro R (2000) 'Inequality and Growth in a Panel of Countries', Journal of Economic Growth, 5(1), 5-32.

Barro R (2008) 'Income and growth revisited', Working Papers on Regional Economic Integration 11, Asian Development Bank, Manila.

Baumol W J (1986) 'Productivity growth, convergence, and welfare: what the long-run data show', American Economic Review, 76(5), 1072-1085.

Beck T (2011) 'Finance and oil: is there a resource curse in financial development?', European Banking Center Discussion Paper 2011-004, Tilburg University, Tilburg, The Netherlands. 
Blanchard O (2006) Macroeconomics, 6e, Upper Saddle River NJ: Pearson Prentice Hall.

Bongaarts J (2002) 'Dependency burdens in the developing world', in Birdsall N, Kelley A C and Sinding S (eds) Population Matters: Demographic change, economic growth, and poverty in the developing world, New York NY: Oxford University Press.

Breusch T and Pagan A (1979) 'A simple test for heteroscedasticity and random coefficient variation', Econometrica, 80(1), 1287-1294.

Caner M, Grennes T and Koehler-Geib F (2010) 'Finding the tipping point: when sovereign debt turns bad, Policy Research Working Paper 5391, Economic Policy Sector, World Bank, Washington DC.

Checherita C and Rother P (2012) 'The impact of High And Growing Government Debt On Economic Growth An Empirical Investigation For The Euro Area', European Economic Review, 56(7), 1392-1405.

Cochrane J (2011) 'Inflation and Debt', National Affairs, 9(2), 56-78.

Diamond D and He Z (2013) 'A theory of debt maturity: the long and short of debt overhang', The Journal of Finance, 69(2), 719-762.

Eberhardt M and Presbitero A (2013) 'This time they're different: heterogeneity and nonlinearity in the relationship between debt and growth', IMF Working Paper 13/248, International Monetary Fund, Washington DC.

Elmendorf D W and Mankiw N G (1999) 'Government debt', in Taylor J B and Woodford M (eds) Handbook of Macroeconomics, 1, Amsterdam: North Holland.

Ghosh A, Kim J, Mendoza E, Ostry J and Qureshi M (2011) 'Fiscal fatigue, fiscal space and debt sustainability in advanced economics', NBER Working Paper Series 16782, National Bureau of Economic Research, Cambridge MA.

Gini C (1921) 'Measurement of inequality of incomes', The Economic Journal, 31(121), 124-126.

Gobbin N, Rayp G and Van de Gaer D (2007) 'Inequality and Growth: From Micro Theory to Macro Empirics', Scottish Journal of Political Economy, 54(4), 508-530.

Gujarati D (2004) Basic Econometrics, 4e, New York NY: McGraw-Hill Education.

Hausman J (1978) 'Specification tests in econometrics', Econometrica, 46(6), 12511271.

Herndon T, Ash M and Pollin R (2013) 'Does high public debt consistently stifle economic growth? A critique of Reinhart and Rogoff', Cambridge Journal of Economics, 38(7), 257-279.

Khan M and Senhadji A (2000) Threshold effects in the relationship between inflation and growth, IMF Working Paper 01/44, International Monetary Fund, Washington DC.

Khan M, Senhadji A and Smith B (2001) 'Inflation and financial depth', IMF Working Paper 00/110, International Monetary Fund, Washington DC.

Kourtellos A, Stengos T and Tan C (2015) Structural threshold regression, Econometric Theory, doi: 10.1017/S0266466615000067. 
Krugman P (1988) 'Financing vs. forgiving a debt overhang', Journal of Development Economics, 129(3), 253-268.

Kumar M and Woo J (2010) 'Public debt and growth', IMF Working Paper 10/174, International Monetary Fund, Washington DC.

Kumhof M and Ranciere R (2010) 'Inequality, leverage and crises', IMF Working Papers 10/268, International Monetary Fund, Washington DC.

Kuznets S (1955) 'Economic growth and income inequality', American Economic Review, 45(1), 1-28.

Law S H and Singh N (2014) 'Does too much finance harm economic growth?', Journal of Banking and Finance, 41, 36-44.

Mankiw N G, Romer D and Weil D (1992) 'A contribution to the empirics of economic growth', Quarterly Journal of Economics, 107(2), 407-437.

Modigliani F (1961) 'Long-run implications of alternative fiscal policies and the burden of the national debt', Economic Journal, 71(1), 730-755.

Nili M and Rastad M (2007) 'Addressing the growth failure of the oil economies: the role of financial development', Quarterly Journal of Economics and Finance, 46, 726-740.

Pagano M (1993) 'Financial markets and growth: an overview', European Economic Review, 37(2), 613-622.

Panizza U and Presbitero A (2013) 'Public debt and economic growth in advanced economies: a survey', Swiss Journal of Economics and Statistics, 149(2), 175-204.

Patillo C, Poirson H and Ricci L (2004) What are the channels through which external debt affects growth? IMF Working Paper 04/15, International Monetary Fund, Washington DC.

Podestà F (2002) 'Recent developments in quantitative comparative methodology: the case of pooled time series cross-section analysis', DSS Papers Soc 3-02, Università degli Studi di Brescia, Brescia.

Pritchett L (1997) 'Divergence, big time', Journal of Economic Perspectives, 11(3), 3-17.

Reinhart C M, Reinhart V R and Rogoff K S (2012) 'Public debt overhangs: advancedeconomy episodes since 1800', Journal of Economic Perspectives, 26(3), 69-86.

Reinhart C M and Rogoff K S (2010) 'Growth in a time of debt', American Economic Review, 100(2), 573-578.

Saint-Paul G (1992) 'Technological choice, financial markets and economic development', European Economic Review, 36(4), 763-781.

Schclarek A (2004) 'Debt and economic growth in developing and industrial countries', Working Paper 2005/34, Department of Economics, Lund University.

Schreiber S (2008) 'The Hausman test statistic can be negative even asymptotically', Journal of Economics and Statistics, 228(4), 394-405.

Shin I (2012) 'Income inequality and economic growth', Economic Modelling, 29, 20492057. 
Ureche-Rangau L and Burietz A (2013) 'One crisis, two crises... the subprime crisis and the European sovereign debt problems', Economic Modelling, 35, 35-44.

Wilcoxon F (1945) 'Individual Comparisons by Ranking Methods', Biometrics Bulletin, $1(6), 80-83$.

Williamson J (1965) 'Regional inequality and the process of national development', Economic Development and Cultural Change, 14, 3-45.

Wooldridge J (2009) Introductory Econometrics, 4e, Mason OH: South-Western CENGAGE Learning.

World Bank (2013) World Development Indicators databank 2013, available online at: http://databank.worldbank.org/data/views/variableselection/selectvariables.aspx?so urce=world-development-indicators

World Institute for Development Economics Research (2013) World Income Inequality Database, available at: http://www.wider.unu.edu/research/Database/en_GB/database

Yitzhaki S (1979) 'Relative deprivation and the Gini coefficient', Quarterly Journal of Economics, 93(2), 321-324.

Young B and Semmler W (2011) 'The European Sovereign Debt Crisis: Is Germany to Blame?', German Politics and Society, 29(1), 1-24. 